\title{
OBCIAŻENIE PSYCHOFIZYCZNE PIELĘGNIAREK PRACUJĄCYCH NA BLOKU OPERACYJNYM URAZOWO-ORTOPEDYCZNYM
}

\section{PSYCHOPHYSICAL WORKLOAD IN NURSES WORKING AT TRAUMATIC AND ORTHOPEDIC SURGERY OPERATING BLOCK}

\author{
Monika Białkowska, , , Jarosław Pasek ${ }^{2,3, b}$, Grzegorz Cieślar ${ }^{3, ~ c}$, Bogdan Koczy, d \\ ${ }^{1}$ Samodzielny Publiczny Wojewódzki Szpital Chirurgii Urazowej im. Janusza Daaba w Piekarach Śląskich \\ ${ }^{2}$ Wydział Nauk o Zdrowiu, Uniwersytet im. Jana Długosza w Częstochowie \\ ${ }^{3}$ Katedra i Oddział Kliniczny Chorób Wewnętrznych, Angiologii i Medycyny Fizykalnej, Wydział Nauk Medycznych w Zabrzu, Śląski Uniwersytet \\ Medyczny w Katowicach
}

${ }^{a}$ https://orcid.org/0000-0003-3143-885X

${ }^{\mathrm{b}} \mathrm{https} / / /$ orcid.org/0000-0001-6181-337x

${ }^{c}$ https://orcid.org/0000-0003-2210-8744

${ }^{\mathrm{d}}$ https://orcid.org/0000-0002-7958-8438

DOI: https://doi.org/10.20883/pielpol.2021.2

\section{STRESZCZENIE}

Wstęp. Zawód wykonywany przez pielęgniarki związany jest z wysokim ryzykiem obciążeń nie tylko fizycznych, ale także psychicznych. Poszczególne oddziały szpitalne różnią się ze względu na formy aktywności zawodowej pielęgniarek. Z tego powodu autorzy podjęli próbę oceny obciążeń psychofizycznych występujących u wybranej grupy pielęgniarek pracujących na bloku operacyjnym urazowo-ortopedycznym.

Cel. Celem badania była analiza obciażeń psychofizycznych pielęgniarek pracujących na bloku operacyjnym urazowo-ortopedycznym.

Materiał i metoda. W badaniu udział wzięło 88 pielęgniarek w wieku od 25-55 lat pracujących zawodowo na bloku operacyjnym urazowo-ortopedycznym. W badaniu zastosowano metodę sondażu diagnostycznego, w którym narzędziem badawczym była ankieta składająca się z 15 pytań dotyczących danych demograficznych, stażu pracy, zajmowanego stanowiska oraz kwestii związanych z występowaniem określonych obciążeń psychicznych i fizycznych.

Wyniki. Aż 65,91\% badanych pielęgniarek wskazało, iż wykonywana przez nie praca związana jest $z$ sytuacjami stresogennymi. Zgłaszane objawy obciążenia psychicznego to: bóle głowy $(60,23 \%)$, zaburzenia koncentracji $(43,18 \%)$ oraz senność $(38,64 \%)$. Objawy dotyczące obciążeń fizycznych odczuwało ponad $95 \%$ badanych pielęgniarek. Dotyczyły one kręgosłupa szyjnego i lędźwiowego (69,32\%), stawów barkowych $(12,5 \%)$ i łokciowych (11,36\%). Najniższą częstość występowania objawów odnotowano $w$ grupie pielęgniarek mających najkrótszy staż pracy 5-10 lat (24,14\%). Częstość występowania tych objawów w przedziałach stażu pracy 10-15 lat i powyżej 15 lat była istotnie wyższa ( $p=0,027$ ) i wynosiła odpowiednio: $66,67 \%$ i $65,22 \%$.

\section{ABSTRACT}

Introduction. The nursing profession is related to a high risk of both physical and psychological workload. Hospital wards differ with regard to the forms of professional activity of nurses. For this reason, the authors made an attempt to evaluate psycho-physical workloads occurring in selected group of nurses working at traumatic and orthopedic operating block.

Aim. The aim of the study was to evaluate the psychophysical workload in nurses working at traumatic and surgery operating block

Material and methods. In the study 88 nurses in age range 25-55 years actively professionally working in the orthopedic and trauma surgery operating block were examined. The survey method was applied with the use of a questionnaire consisting of 15 questions regarding demographic data, time of professional practice, the position held, as well as the occurrence of specific psychological and physical workload.

Results. As many as $65,91 \%$ of participating nurses indicated that their work was related to stressful situations. Related symptoms of mental fatigue were headache $(60.23 \%)$, impaired concentration (43.18\%) and sleepiness (38.64\%). Symptoms regarding physical loads were felt by over $95 \%$ of nurses. It concerned cervical and lumbar spine (69.32\%), shoulder joints (12.5\%) and elbow joints (11.36\%). The lowest frequency of symptoms was observed in group of nurses with shortest time of job seniority $5-10$ years $(24.14 \%)$. Whereas, the frequency of appearance of those symptoms in time ranges of job seniority between 10-15 years and above 15 years was significantly higher $(p=0.027)$ and it amounted: $66.67 \%$ and $65.22 \%$, respectively. 
Wnioski. Praca pielęgniarek na bloku operacyjnym urazowo-ortopedycznym obarczona jest licznymi obciążeniami psychicznymi i fizycznymi. Dominujące obciążenie w sferze psychicznej stanowi stres, natomiast obciążenia fizyczne związane są z zaburzeniami strukturalnymi i dolegliwościami bólowymi ze strony narządu ruchu. Częstość występowania odczuwanych dolegliwości zależna jest od długości stażu pracy na bloku operacyjnym.

SŁOWA KLUCZOWE: pielęgniarki, blok operacyjny, obciążenia psychofizyczne, stres.

\section{Wstęp}

Blok operacyjny nazywany jest ,sercem szpitala”, w którym przeprowadza się zabiegi operacyjne. Ponieważ łączność pomiędzy izbą przyjęć, oddziałami a blokiem operacyjnym jest nieodzowna, najczęściej usytuowany jest on w miejscu, które pozwala na szybki transport pacjentów z oddziałów szpitalnych oraz izby przyjęć i zazwyczaj znajduje się nad centralną sterylizatornią. Nowo zaprojektowany blok operacyjny musi spełniać wszystkie normy i wymogi, które są zawarte w odpowiednich aktach prawnych [1, 2].

Blok operacyjny jest niezwykle specyficznym miejscem pracy. Personel tam pracujący musi wykonywać pracę zgodnie z wymogami, obowiązującymi procedurami i posiadanymi umiejętnościami, a także przestrzegać etyki zawodowej. W każdej sytuacji musi być gotowy do udzielenia pierwszej pomocy pacjentowi, gdy zajdzie taka potrzeba [3].

Nowoczesne bloki operacyjne zwykle posiadają więcej sal operacyjnych. Przekłada się to na większe obciążenia pracą osób tam pracujących oraz większe prawdopodobieństwo narażenia personelu na różnego rodzaju zagrożenia, do których należą przede wszystkim obciążenia fizyczne, psychiczne, biologiczne oraz chemiczne. Najczęściej na bloku operacyjnym występuje kilka wspomnianych powyżej obciążeń jednocześnie [4].

Praca personelu pielęgniarskiego należy do jednych z najbardziej odpowiedzialnych i obciążających zawodów medycznych. Jest to związane ze sprawowaniem opieki nad pacjentami w aspekcie ratowania ludzkiego zdrowia i życia. Od zespołu pielęgniarskiego wymaga się obok odpowiedniego poziomu wykształcenia zawodowego i umiejętności manualnych, także bardzo wszechstronnego przygotowania merytorycznego i psychologicznego w zakresie sprawowanej opieki nad pacjentem. Praca wykonywana przez pielęgniarki na bloku operacyjnym wiąże się z dużymi obciążeniami zarówno psychicznymi, jak i fizycznymi. Do obciążeń psychicznych zalicza się czynniki stresogenne, do których należą: czynności wykonywane przy pacjencie,
Conclusions. The position of nurses at the trauma and orthopedic surgery operating block is connected with numerous psychical and physical workloads. The dominant workload in the psychic sphere is stress, while physical loads are associated with pain ailments in the musculoskeletal system. The frequency of ailments is related to the time of job seniority at operating block.

KEYWORDS: nurses, operating block, psychophysical workload, stress.

asystowanie do zabiegów operacyjnych, w tym zwłaszcza wieloprofilowych wykonywanych u pacjentów z mnogimi urazami, wieloprofilowość bloków operacyjnych, w których stosowane są zróżnicowane techniki operacyjne, odpowiedzialność za życie drugiego człowieka, obcowanie ze śmiercią, w tym zgony pacjentów w czasie trwania zabiegów oraz po zabiegach operacyjnych, konflikty interpersonalne oraz konieczność pozostawania w ciągłej gotowości do pracy. Inne czynniki stresogenne występujące w pracy pielęgniarki to również konieczność nieustannej koncentracji uwagi, zwłaszcza podczas wykonywania trudnych zadań wymagających intensywnej pracy umysłowej, precyzyjności, bezbłędności i dyspozycyjności, praca zmianowa (wbrew zegarowi biologicznemu), niedobory kadrowe oraz niemożność pogodzenia obowiązków wobec rodziny z obowiązkami w pracy [5, 6].

Obciążenia fizyczne związane są przede wszystkim z wykonywaniem pracy w pozycji stojącej (często w nieergonomicznym pochyleniu tułowia do przodu, które może trwać nawet do kilku godzin), dźwiganiem zestawów z narzędziami i sprzętu medycznego oraz przenoszeniem pacjentów ze stołu operacyjnego na łóżko i odwrotnie. Takie sytuacje prowadzą do powstawania zaburzeń przeciążeniowych, których konsekwencją są początkowo zmiany czynnościowe, a następnie strukturalne w obrębie narządu ruchu. Do najczęstszych dolegliwości fizycznych zgłaszanych przez zespoły pielęgniarskie pracujące na blokach operacyjnych należą bóle kręgosłupa, kończyn dolnych oraz głowy [7, 8].

Powyższe informacje wskazują na potrzebę prowadzenia dalszych badań dotyczących obciążenia pracą zawodową u pielęgniarek zatrudnionych na różnych oddziałach szpitalnych, posiadających często odmienną specyfikę warunków pracy oraz różniących się charakterem czynności zawodowych wykonywanych przez pracujące w nich pielęgniarki. Dlatego autorzy pracy podjęli próbę oceny obciążeń psychofizycznych występujących u wybranej grupy pielęgniarek pracujących na bloku operacyjnym urazowo-ortopedycznym. 


\section{Cel pracy}

Celem badania była analiza obciążeń psychofizycznych pielęgniarek pracujących na bloku operacyjnym urazowo-ortopedycznym.

\section{Materiał i metoda badań}

W badaniu przeprowadzonym w 2019 roku udział wzięto 88 pielęgniarek (70 pielęgniarek z grupy zawodowej instrumentariuszek i 18 pielęgniarek anestezjologicznych) pracujących zawodowo na bloku operacyjnym urazowo-ortopedycznym w Samodzielnym Publicznym Wojewódzkim Szpitalu Chirurgii Urazowej w Piekarach Śląskich w wieku 25-55 lat, ze średnim stażem pracy -16 lat.

Kryteriami włączenia do badania były: płeć żeńska, staż pracy - minimum 5 lat oraz zgoda pielęgniarki na udział $\mathrm{w}$ badaniu. Natomiast kryteriami wyłączenia z badania były: płeć męska, staż pracy poniżej 5 lat oraz brak zgody pielęgniarki na udział $w$ badaniu.

W badaniu zastosowano metodę sondażu diagnostycznego, w którym narzędziem badawczym była autorska anonimowa ankieta składająca się z 15 pytań dotyczących podstawowych danych demograficznych (wiek, płeć, wykształcenie, miejsce zamieszkania), stażu pracy na bloku operacyjnym, zajmowanego stanowiska oraz kwestii związanych z występowaniem określonych obciążeń psychicznych i fizycznych podczas pracy na bloku operacyjnym.

\section{Analizy statystyczne}

Do oceny istotności zależności pomiędzy zmiennymi jakościowymi zastosowano test chi-kwadrat. Przyjęto poziom istotności $p<0,05$. Do analizy pozostałych danych posłużono się statystyką opisową. Do analizy statystycznej wykorzystano programy Statistica $12 \mathrm{PL}$ i MS Excel 2016.

\section{Wyniki}

W tabeli 1 przedstawiono charakterystykę badanej grupy pielęgniarek pracujących na bloku operacyjnym urazowo-ortopedycznym.

Tabela 1. Charatkerystyka badanej grupy pielęgniarek pracujących na bloku operacyjnym urazowo-ortopedycznym ( $\mathrm{N}=88$ )

Table 1. Characteristics of the examined group of nurses working at the trauma and orthopaedic operating block $(N=88)$

\begin{tabular}{cccc}
\hline Wiek/ & $25-35$ lat/ & $36-45$ lat/ & $46-55$ lat/ \\
age & years & years & years \\
& $27(30,68 \%)$ & $43(48,86 \%)$ & $18(20,46 \%)$ \\
\hline \multirow{3}{*}{$\begin{array}{c}\text { Wykształcenie/ } \\
\text { education }\end{array}$} & Średnie/ & Wyższe/ & mgr pielęgniar- \\
& medium & higher & stwa/ \\
& $33(37,50 \%)$ & $47(53,41 \%)$ & $8(9,09 \%)$
\end{tabular}

$\begin{array}{lccc}\begin{array}{l}\text { Staż pracy na } \\ \text { bloku opera- } \\ \text { cyjnym/lenght } \\ \text { of service } \\ \text { at operating } \\ \text { block }\end{array} & \begin{array}{c}5-10 \text { lat/ } \\ \text { years }\end{array} & \begin{array}{c}10-15 \text { lat/ } \\ \text { years }\end{array} & \begin{array}{c}\text { Powyżej } 15 \text { lat/ } \\ \text { above } 15 \text { years }\end{array} \\ \begin{array}{l}\text { Zajmowane } \\ \text { stanowisko/ }\end{array} & \begin{array}{c}\text { pielegniarka instrumentariuszka/ } \\ \text { operating room nurse }\end{array} & \begin{array}{c}\text { pielegniarka } \\ \text { anestezjologiczna/ } \\ \text { anaesthetic nurse }\end{array} \\ \text { position } & 76(40,91 \%) & 23(26,14 \%)\end{array}$

Źródło: opracowanie własne

Source: author's own analysis

W badanej grupie średni wiek pielęgniarek wynosił 36 lat. Najliczniejszą grupę stanowiły pielęgniarki w przedziale wiekowym $35-45$ lat (48\%), a najmniej liczną pielęgniarki w przedziale wiekowym 46-55 lat 22 (22\%) osoby. Pięćdziesiąt pięć pielęgniarek (62,5\%) posiadało wykształcenie wyższe, natomiast pozostałe $33(37,5 \%)$ pielęgniarki wykształcenie średnie zawodowe. Średni staż pracy na bloku operacyjnym w całej badanej grupie wynosił 16 lat. Najliczniejszą grupę stanowiło 36 (40,91\%) pielęgniarek, których średni staż pracy zawierał się w przedziale 10-15 lat. Najmniej liczną grupę stanowiły $23(26,14 \%)$ pielęgniarki posiadające staż pracy powyżej 15 lat. Zdecydowana większość (79,55\%) pielęgniarek wykonywała czynności pielęgniarki-instrumentariuszki, natomiast pozostałe $20,45 \%$ stanowiły pielęgniarki anezstezjologiczne. Wynikało to z faktu, iż do zabiegu operacyjnego potrzebna jest tylko jedna pielęgniarka anestezjologiczna oraz 2 pielęgniarki instrumentariuszki, a dodatkowo na bloku operacyjnym niezbędne są również instrumentariuszki, które muszą zadbać o dostarczenie sterylnych zestawów narządzi chirurgicznych niezbędnych do przeprowadzenia zabiegu operacyjnego.

W tabeli 2 przedstawiono odpowiedzi badanych pielęgniarek na pytania ankiety dotyczące rodzaju obciążeń psychicznych występujących podczas pracy na bloku operacyjnym urazowo-ortopedycznym.

Według $65,91 \%$ badanych pielęgniarek praca wykonywana na bloku operacyjnym wywołuje reakcje stresowe. Były one związane m.in. z pojawiającymi się „sytuacjami trudnymi” podczas pracy, na co wskazało aż $78,41 \%$ badanych pielęgniarek. Zdarzały się także konflikty interpersonalne występujące najczęściej na linii pielęgniarka-pielęgniarka oraz pielęgniarka-lekarz, co potwierdziło $55.68 \%$ badanych pielęgniarek. 
Tabela 2. Odpowiedzi na pytania dotyczące rodzaju obciążeń psychicznych występujących na bloku operacyjnym urazowo-ortopedycznym Table 2. Answers to questions regarding the type of psychological burdens occurring at the trauma and orthopaedic operating block

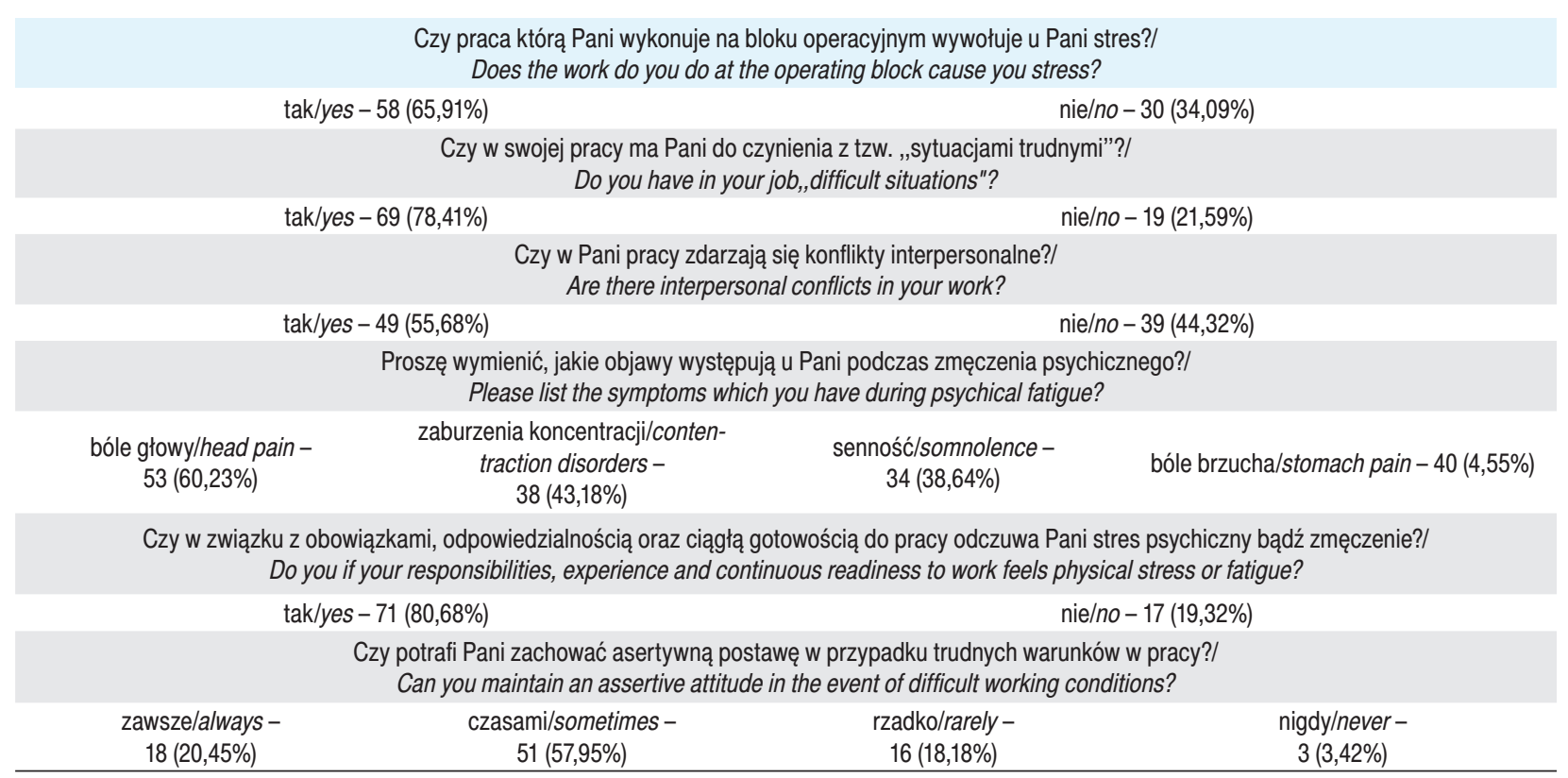

Źródło: opracowanie własne

Source: author's own analysis

W badanej grupie pielęgniarek najczęstszymi objawami zmęczenia psychicznego były: bóle głowy $(60,23 \%)$, zaburzenia koncentracji $(43,18 \%)$ oraz senność (38,64\%). Aż u 80,69\% badanych pielęgniarek przyczyną zmęczenia psychicznego były sytuacje stresowe związane z powierzanymi obowiązkami, dużą odpowiedzialnością oraz utrzymywaniem ciągłej gotowości do pracy. Istotne znaczenie miał również fakt, że w przypadku trudnych warunków występujących w pracy większość badanych pielęgniarek $(79,55 \%)$ nie potrafiła zachować postawy asertywnej, zachowywała ją rzadko lub jedynie czasami. Trudne warunki w pracy związane były głównie z długim asystowaniem przy zabiegach operacyjnych oraz wykonywaniem kilku czynności w jednym czasie.

W tabeli 3 przedstawiono odpowiedzi badanych pielęgniarek na pytania dotyczące rodzaju obciążeń fizycznych podczas pracy na bloku operacyjnym urazowo-ortopedycznym.

Tabela 3. Odpowiedzi na pytania dotyczące obciążeń fizycznych występujących w badanej grupie pielęgniarek Table 3. Answers to questions about physical burdens occurring in the examined group of nurses

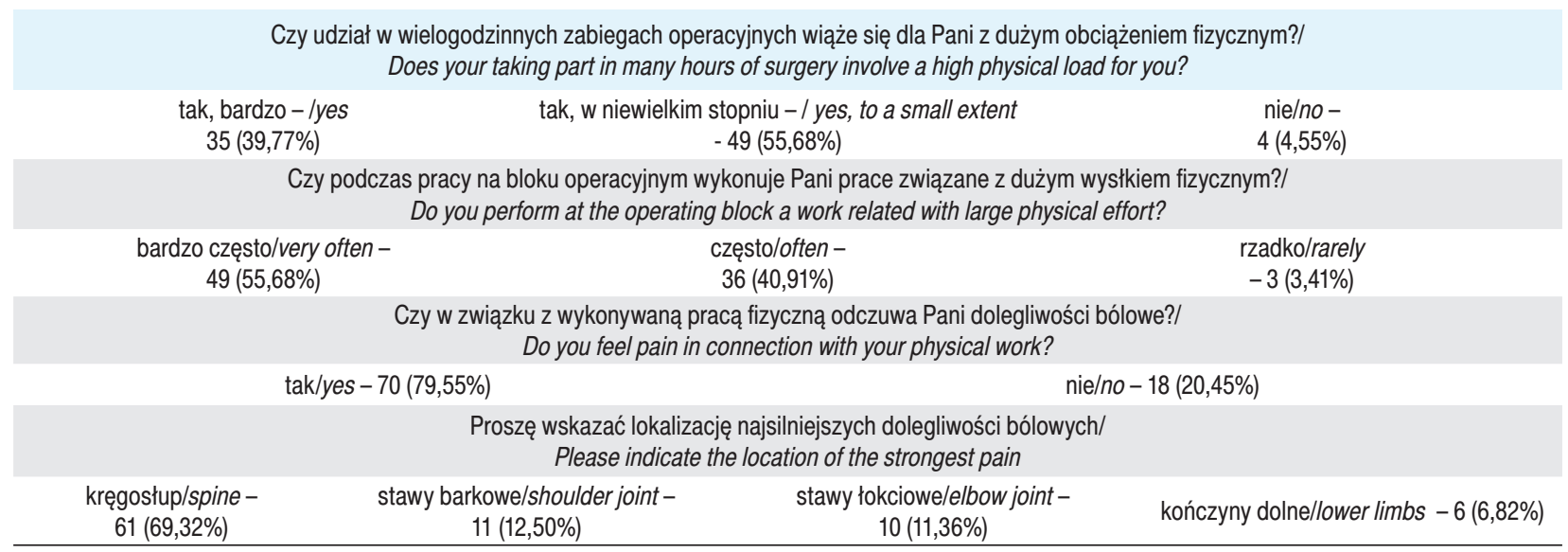

Źródło: opracowanie własne

Source: author's own analysis 
Asystowanie do wielogodzinnych zabiegów operacyjnych dla $39,77 \%$ badanych pielęgniarek wiązało się z bardzo dużym obciążeniem fizycznym, dla 55,68\% badanych pielęgniarek z niewielkim obciążeniem, a jedynie dla 4,55\% (będących w grupie wiekowej poniżej 35 r.ż.) nie stanowiło obciążenia fizycznego. 55,68\% badanych potwierdziło, że podczas pracy na bloku operacyjnym wykonuje bardzo często czynności związane z dużym wysiłkiem fizycznym. Związane było to m.in. z przenoszeniem/podnoszeniem pacjentów oraz przenoszeniem ciężkich tac z narzędziami chirurgicznymi i sprzętem medycznym. Natomiast 40,91\% badanych wskazało, że takie czynności wykonuje często. Aż 79,55\% badanych pielęgniarek potwierdziło, że odczuwa nasilone dolegliwości bólowe z powodu podnoszenia ciężkich zestawów chirurgicznych lub pracy związanej z transportem pacjentów. Najczęstszą lokalizacą odczuwanych dolegliwości bólowych były: kręgosłup szyjny i lędźwiowy (69,32\% badanych), stawy barkowe (12,50\% badanych) oraz stawy łokciowe (11,36\% badanych).

Analiza uzyskanych odpowiedzi wykazała istnienie zależności pomiędzy stażem pracy a częstością występowania objawów zmęczenia fizycznego (przejawiającego się dolegliwościami ze strony narządu ruchu) oraz objawów stresu psychicznego. Najniższą częstość ich występowania odnotowano w grupie pielęgniarek mających najkrótszy staż pracy, mieszczący się w przedziale 5-10 lat (24,14\%). Częstość występowania tych objawów w przedziałach stażu pracy 10-15 lat i powyżej 15 lat była istotnie wyższa $(p=0,027)$ i wynosiła odpowiednio: $66,67 \%$ i $65,22 \%$ (tabela 4).

\section{Dyskusja}

Z przeprowadzonego badania wynika, że praca na bloku operacyjnym urazowo-ortopedycznym powoduje występowanie obciążeń psychicznych, w tym głównie stresu i zmęczenia psychicznego. Dotyczy to zwłaszcza pielęgniarek o dłuższym stażu pracy. Zmęczenie psychiczne objawia się u nich zwykle zaburzeniami koncentracji, bólami głowy oraz sennością.

Przyczyną stresu w warunkach pracy bloku operacyjnego jest przede wszystkim występowanie „sytuacji trudnych" oraz konfliktów interpersonalnych pomiędzy różnymi grupami pracowników medycznych. Pojawianie się obu tych zjawisk na bloku operacyjnym jest nieuniknione. Powstawanie wielu niezamierzonych sytuacji stresowych i napięć wynika m.in. z wykonywania ciężkiej pracy fizycznej podczas długotrwałych zabiegów, prowadzonych często w sytuacji zagrożenia zdrowia iżycia pacjenta. Dodatkowym czynnikiem prowadzącym do rozwoju sytuacji konfliktowych jest konieczność pracy w wieloosobowym zespole przebywającym ze sobą na niewielkiej przestrzeni przez długi okres czasu.

Badanie wykazało również, że nadmierne obciążenia fizyczne podczas pracy na bloku operacyjnym powodują występowanie dolegliwości bólowych kręgosłupa, najczęściej odczuwanych w odcinku szyjnym i lędźwiowym. Związane jest to z wielogodzinnym asystowaniem do zabiegów w pozycji stojącej i bardzo często w nieprawidłowej postawie ciała. Podobne rezultaty uzyskali Darli Rde C. i wsp. [9], którzy dokonali oceny dolegliwości ze strony narządu ruchu występujących u 95 pielęgniarek w wieku od 23 do 61 lat. Wśród proble-

Tabela 4. Zależność pomiędzy stażem pracy a występowaniem objawów zmęczenia fizycznego i stresu psychicznego Table 4. The relationship between job seniority and frequency of symptoms of physical fatigue and mental stress

\begin{tabular}{|c|c|c|c|c|c|c|}
\hline & \multicolumn{6}{|c|}{ Staż pracy na bloku operacyjnym/Job seniority at the operating block } \\
\hline & \multicolumn{2}{|c|}{ 5-10 lat/years } & \multicolumn{2}{|c|}{ 10-15 lat/years } & \multicolumn{2}{|c|}{ Powyżej 15 lat/above 15 years } \\
\hline \multirow[t]{2}{*}{$\mathrm{N}$} & \multicolumn{2}{|c|}{29} & \multicolumn{2}{|c|}{36} & \multicolumn{2}{|c|}{23} \\
\hline & tak/yes & nie/no & tak/yes & nie/no & tak/yes & nie/no \\
\hline \multirow{2}{*}{$\begin{array}{l}\text { Występowanie objawów zmęcze- } \\
\text { nia fizycznego i stresu psychiczne- } \\
\text { go/Occurrence of physical fatigue } \\
\text { and mental stress symptoms }\end{array}$} & $\begin{array}{c}7 \\
(24,14 \%)\end{array}$ & $\begin{array}{c}22 \\
(75,86 \%)\end{array}$ & $\begin{array}{c}24 \\
(66,67 \%)\end{array}$ & $\begin{array}{c}12 \\
(33,33 \%)\end{array}$ & $\begin{array}{c}15 \\
(65,22 \%)\end{array}$ & $\begin{array}{c}8 \\
(34,78 \%)\end{array}$ \\
\hline & \multicolumn{6}{|c|}{$p=0,027$} \\
\hline
\end{tabular}

Źródło: opracowanie własne

Source: author's own analysis 
mów związanych z obciążeniem fizycznym pielęgniarki zgłaszały m.in.: bóle pleców, zmęczenie/wyczerpanie, sztywność karku i niestrawność żołądka.

Stwierdzone w badaniu częstsze występowanie dolegliwości wynikających z obciążeń psychofizycznych na bloku operacyjnym urazowo-ortopedycznym w grupach pielęgniarek z dłuższym stażem pracy prawdopodobnie wynika z faktu przewlekłego oddziaływania tych czynników. Długotrwałe obciążenia, zwłaszcza fizyczne, powodują u pielęgniarek ze starszych grup wiekowych występowanie zaawansowanych zmian w obrębie narządu ruchu o charakterze strukturalnym wywołujące bardziej nasilone dolegliwości kliniczne. Natomiast w przypadku pielęgniarek o krótszym stażu pracy zmiany w obrębie narządu ruchu mają charakter głównie czynnościowy i nie powodują jeszcze częstego występowania odczuwalnych dolegliwości.

Od personelu pielęgniarskiego pracującego na blokach operacyjnych wymaga się szczególnego zaangażowania, posiadania odpowiedniej wiedzy, umiejętności oraz samodyscypliny. Każde niedopatrzenie, niedokładność i rozkojarzenie może kosztować ludzkie zdrowie lub życie. Wyniki przeprowadzonego badania dowodzą, że ta trudna i obciążająca praca w konsekwencji skutkuje licznymi obciążeniami psychofizycznymi, których częstość występowania narasta wraz z czasem trwania stażu pracy na bloku operacyjnym.

\section{Wnioski}

1. Praca pielęgniarek na bloku operacyjnym urazowo-ortopedycznym obarczona jest licznymi obciążeniami psychicznymi i fizycznymi.

2. Dominujące obciążenie w sferze psychicznej stanowi stres. Obciążenia fizyczne związane są z dolegliwościami bólowymi ze strony narządu ruchu, w szczególności kręgosłupa oraz stawów barkowych i łokciowych.

3. Częstość występowania dolegliwości zależna jest od długości stażu pracy na bloku operacyjnym. Jest ona wyższa wśród pielęgniarek o dłuższym stażu pracy (powyżej 10 lat).

\section{Piśmiennictwo}

1. Bielecki K, Szretera T. Blok operacyjny - organizacja i funkcjonowanie, ryzyko. Wydawnictwo Medyczne Borgis. Warszawa 2007, 177-178.

2. Broncel-Czekaj D. Współpraca bloku operacyjnego i centralnej sterylizatorni - element niezbędny. Ogólnopol. Przegl. Med. 2013; 11: 18-21.

3. Ciuruś M. Pielęgniarstwo operacyjne. Wydawnictwo Makmed. Lublin 2007, 36-61.

4. Ślusarska B, Zarzycka D, Zahradniczek K. Podstawy pielęgniarstwa. Założenia teoretyczne. Wydawnictwo Czelej sp. z o.o. Lublin 2004, 25-32.

5. Figurska I. Stres w pracy instrumentariuszki. Biul. Instrumentariuszek Ortop. 2010; 8(2): 205-212.

6. Kułagowska E, Kosińska M. Obciążenie układu mięśniowo-szkieletowego podczas prac wykonywanych przez pielęgniarkę anestezjologiczną. Med. Prakt. 2008: 59(4): 287-292.

7. Kuduk M, Kotlarz B. Czynniki ryzyka zawodowego na stanowisku pracy pielęgniarki i położnej. Nasze Sprawy. 2010; 9: 20-23.

8. Leszczyńska A, Daniszewska B, Dudek K i wsp. Wpływ ergonomii pracy pielęgniarek na występowanie dolegliwości bólowych w obrębie kręgosłupa. Kwart. Ortop. 2008; 2: 210-211.

9. Dalri Rde C, da Silva LA, Mendes AM. Nurses' workload and its relation with physiological stress reactions. Rev. Lat. Am. Enfermagem. 2014; 22(6): 959-965.

Artykuł przyjęty do redakcji: 28.04.2020.

Artykuł przyjęty do publikacji: 13.07.2020.

Źródło finansowania: Praca nie jest finansowana z żadnego źródła. Konflikt interesów: Autorzy deklarują brak konfliktu interesów.

\author{
Adres do korespondencji: \\ Jarosław Pasek \\ ul. Batorego 15 \\ 41-902 Bytom \\ e-mail: jarus_tomus@o2.pl \\ Katedra i Oddział Kliniczny Chorób Wewnętrznych, Angiologii \\ i Medycyny Fizykalnej Śląskiego Uniwersytetu Medycznego \\ w Katowicach
}

